\title{
Dentists fully support HPV jabs for boys
}

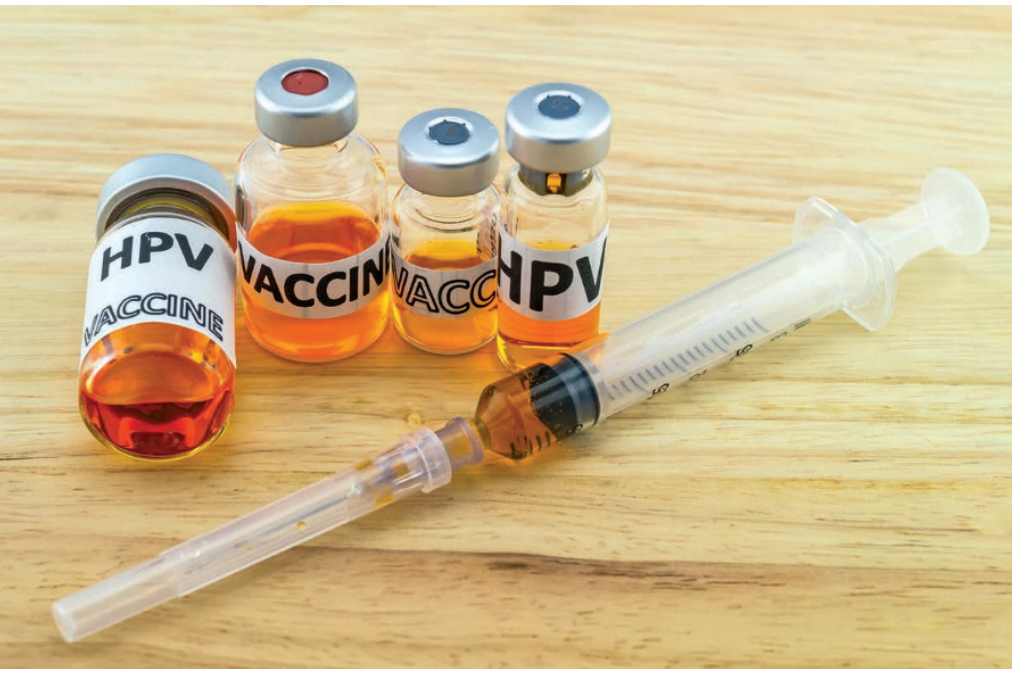

The overwhelming majority of dentists and GPs are backing calls . expanded to school-aged boys, according to a new survey.

In the new poll published by the campaign coalition HPV Action for World Immunisation Week (24-28 April), 97\% of dentists backed 흥 expansion of the programme, with the same proportion saying if they had a son they would want them to receive the vaccination. Ninetyfour percent of GPs said they would support both positions.

The survey was sent to members of the British Dental Association (BDA), the Faculty of General Dental Practice (UK) (FGDP[UK]) and the British Medical Association (BMA). Findings come as the Government's vaccination advisory committee (JCVI) moves towards a decision on whether boys should be given the HPV vaccination.

Up to $80 \%$ of sexually active people will be infected by HPV at some point in their lives. Five percent of all cancers are caused by HPV and some of these, notably oral cancers, are now rising sharply in incidence. HPV-related cancers, such as anal cancer, are also among the hardest to diagnose and treat.

Parliamentarians from all parties have signed an open letter to the Health Secretary, Jeremy Hunt MP, urging him to ensure that the UK doesn't miss this opportunity to eradicate some of the fastest rising cancers in the developed world.

Mick Armstrong, Chair of the BDA's Principal Executive Committee (PEC), said: 'HPV is the leading cause of oro-pharyngeal cancers and men are just as likely to develop it as women so where is the logic - or fairness - in targeting protection to one section of the population? It is morally indefensible to allow people to contract cancer when prevention - the new NHS mantra - could be so cheap and easy. Cancers affecting the mouth and throat have a huge impact on the quality of people's lives, so it's frustrating for dentists, who are often the first to detect them, knowing how easily they could have been prevented.'

Mick Horton, Dean of the Faculty of General Dental Practice (UK), said: 'The incidence of oral cancer has increased dramatically over the last decade, and over two-thirds of diagnoses are in men. HPV is a main causative agent, and the introduction of the NHS vaccination programme for girls has led to a significant reduction in the prevalence of the virus among women. Yet with over 2,000 men a year in the UK diagnosed with an HPV-related cancer - of whom almost half will die from the condition within five years - it is clear that current measures are not working for everyone. The view of oral health professionals is resounding - many of these lives could and should be saved by also vaccinating boys against HPV'.

HPV Action is asking members of the public, especially the parents of boys, to sign an online petition demanding gender-neutral vaccination (http://bit.ly/2nHaUul) and will be calling on all political parties to commit themselves to gender-neutral HPV vaccination during the forthcoming General Election campaign.

BRITISH DENTAL CONFERENCE AND EXHIBITION

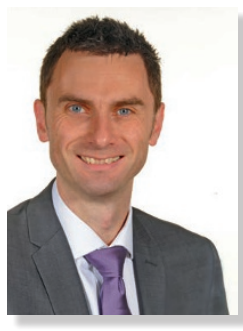

\section{BDJ Pick: Justin Durham}

Dr Justin Durham will be speaking at this year's British Dental Conference and Exhibition on Temporomandibular disorders (TMD) - The Main Details. Justin is a Senior Lecturer/ Honorary Consultant Oral Surgeon at Newcastle University School of Dental Sciences, and NIHR Clinician Scientist.

Justin will be speaking from 12:15-13:15 on Friday 26 May in the Exchange Auditorium at the British Dental Conference and Exhibition in Manchester. To register and download the programme, visit www. bda.org/conference.

\section{King's MI students to receive awards in Manchester}

At this year's British Dental Conference and Exhibition in Manchester, Stephen Hancocks OBE, BDJ Editor-in-Chief, and Avijit Banerjee, Professor of Cariology and Operative Dentistry/
Hon Consultant, Restorative Dentistry, King's College London Dental Institute, will chair an interactive panel session on minimum intervention (MI) management of patients (Friday 26 May 14:30, Exchange Auditorium).

During this vibrant interactive session, hosted by the $B D J$, the chairs and their panel guests will explore, through real-life case studies faced by hard-working, coal-face clinicians every day, a range of clinical/business/behavioural/medico-legal aspects of minimal intervention oral healthcare delivery. Delegates will be able to take home some practical tips on how to develop their MI oral healthcare practice. Following this, two King's postgraduate students on the Advanced Minimum Intervention Dentistry MSc course will be awarded the prestigious Patricia Santos Memorial Scholarship prizes, sponsored by Simplyhealth Professionals, Oral-B and GC UK, at the King's College London exhibition stand (C63).

www.bda.org/Conference/Pages/conference-sessions.aspx?id=142 www.kcl.ac.uk/midentistry 